\title{
Non-invasive laboratory, imaging and elastography markers in predicting varices with high risk of bleeding in cirrhotic patients
}

\author{
ANA PETRISOR ${ }^{1,2}$, ANA MARIA ALEXANDRA STANESCU $^{3}$, IOANA RALUCA PAPACOCEA $^{4}$, \\ EUGENIA PANAITESCU ${ }^{5,6}$, RAZVAN PEAGU $^{1,2}$, ALEXANDRU CONSTANTIN MOLDOVEANU $^{1,2}$, \\ CARMEN FIERBINTEANU-BRATICEVICI ${ }^{1,2}$ \\ ${ }^{1}$ Carol Davila University of Medicine and Pharmacy, Gastroenterology and Internal Medicine II Clinic - University Emergency \\ Hospital Bucharest, Bucharest, Romania \\ ${ }^{2}$ University Emergency Hospital Bucharest, Gastroenterology Department Bucharest, Romania \\ ${ }^{3}$ Carol Davila University of Medicine and Pharmacy, Family Medicine Department, Romania \\ ${ }^{4}$ Carol Davila University of Medicine and Pharmacy, Physiology Department 1, Bucharest, Romania \\ ${ }^{5}$ Carol Davila University of Medicine and Pharmacy, Medical Informatics and Biostatistics, Bucharest, Romania \\ ${ }^{6}$ Carol Davila University of Medicine and Pharmacy, Intensive Computing and Computational Medicine Centre, \\ Bucharest, Romania
}

\begin{abstract}
Introduction. Upper digestive tract endoscopy remains the gold-standard for detecting esophageal or gastric varices and assessment of bleeding risk, but this method is invasive. The aim of the study was to identify non-invasive factors that could be incorporated into an algorithm for estimating the risk of variceal bleeding.

Methods. A prospective study was performed on 130 cirrhotic patients. Tests were performed on all patients which included liver enzymes, complete blood count and coagulation parameters, abdominal ultrasound, elastography of both the liver and the spleen. Upper gastrointestinal endoscopy was performed in all patients included in the study and the results were classified, in accordance with Baveno VI into 2 outcome groups: Group 1 - patients with low bleeding risk and Group 2 - patients with varices needing treatment.

Results. The study lot (130 patients) was divided into: Group I (low bleeding risk - 102 patients), and Group II (high bleeding risk - 28 patients). Parameters found to have significant differences in univariate analysis were transaminases, platelet count, spleen size, INR, portal vein diameter and both liver and spleen elastography. Calculating AUROC for each parameter identifies spleen elastography as having the best result, followed by INR, AST and platelet count. Liver elastography had the worst AUROC. Independent variables identified by logistic regression included spleen elastography, INR, platelet count, spleen diameter, ALT, age, and gender.

Conclusions. Spleen stiffness is the best single parameter predicting the presence of high-risk esophageal varices.
\end{abstract}

Key words: liver cirrhosis, esophageal and gastric varices, gastrointestinal hemorrhage, elasticity imaging techniques.

\footnotetext{
What is new? What is important?

- Spleen elastography was the more accurate method in our study of predicting high risk esophageal varices.

- The accuracy of spleen elastography is significantly better than the more frequently known and used liver elastography.

- Other parameters tested, including AST, ALT, platelet count, spleen size, INR, portal vein diameter, liver elastography were much weaker in diagnosing the presence of varices with a high risk of bleeding.
}

\section{INTRODUCTION}

Upper gastrointestinal bleeding is one of the most important gastroenterological emergencies and is a major cause of mortality. Esophageal, gastric and/or rectal varices are present in almost $50 \%$ [1] of patients diagnosed with liver cirrhosis and bleeding occurs in $25-40 \%$ of patients 
diagnosed with liver cirrhosis. Each episode of variceal bleeding is associated with a mortality of $15-20 \%$, and the risk of repeated bleeding at 1 year is $70 \%$ with a mortality of $33 \%$, in the absence of treatment.

The risk of variceal bleeding depends mainly on three factors: the severity of liver disease (assessed by the Child-Pugh classification) [2,3], the size of the varices and the presence of visible endoscopic stigmas of bleeding: "red wale marks" (longitudinal red streaks along the varices), "cherry red spots" (red spots, discrete, flattened), hemolytic spots (red, elevated) or diffuse erythema [4].

The latest Baveno consensus (VI) states that patients with hepatic elastography measured by transient elastography with a value under $20 \mathrm{kPa}$ and a platelet count of over $150,000 \mathrm{cell} / \mathrm{mm}^{3}$ have a very low risk of having varices requiring treatment and can avoid screening endoscopy [5]. Unfortunately, the number of endoscopies avoided using the Baveno VI criteria is low [6].

Thus, the main objective of this study was to assess various non-invasive methods of screening patients with high-risk varices.

\section{MATERIALS AND METHODS}

\section{Study design}

Inclusion criteria were histologically or noninvasively determined liver cirrhosis (regardless of etiology) that has been either newly diagnosed or very recently diagnosed $(<3$ months), age $>18$ years old, willingness to participate in study (signed informed consent).

Exclusion criteria included acute hepatitis (regardless of etiology), acute on chronic liver disease, recent upper gastrointestinal bleeding, already established high risk varices and chronic treatment (beta-blockers), already established cirrhosis (>3 months since initial diagnosis).

For each group of patients, demographic and epidemiological characteristics were noted - gender, age, etiology of cirrhosis. Laboratory blood tests were performed, which included liver enzymes (aspartate aminotransferase and alanine aminotransferase), complete blood count (thrombocyte count was noted) and coagulation parameters (prothrombin time, international normalized ratio).

Ultrasound was also performed, and parameters of interest included portal vein diameter, anteroposterior diameter of the spleen. The ultrasound device used was Acuson S2000 (Siemens AG, Munich, Germany).

Upper gastrointestinal endoscopy was performed in all patients included in the study and the results were classified, in accordance with Baveno VI [7], into 2 outcome groups: Group 1 - patients with low bleeding risk and Group 2 - patients with varices needing treatment (high bleeding risk - either large varices or varices with red wales) [7]. In addition, the presence of stigmas associated with an increased risk of hemorrhage was noted $[8,9]$.

\section{Acoustic radiation force impulse elastography}

The ultrasound device had an elastography module implemented, and elastography of the liver and spleen was performed for each patient. Values noted in elastography were a ten-measurement average for each organ and standard deviation of the measurements. In the case of spleen elastography, the measurements were performed at $2 \mathrm{~cm}$ depth, under the capsule

The acoustic wave elastography technique functions as follows: during standard abdominal ultrasound, the device creates an acoustic force wave that distorts the tissue through which it passes. The distortion causes the formation of lateral shear waves, that travel through the tissue more rapidly (stiff tissue) or more slowly (soft tissue). The shear waves are observed through the ultrasound, and the device calculates the speed of the shear waves as a proxy for tissue stiffness.

\section{Statistical analysis}

The statistical analysis was performed using SPSS Statistics (International Business Machines Corporation, Armonk, New York, USA) Version 20 and Python (Python Software Foundation, Delaware, United States) with the Pandas and Statsmodels libraries. The statistical significance threshold used was $\alpha=0.05(\mathrm{p}<0.05)$. Statistical association was determined using Independent Samples $\mathrm{T}$ Test, Mann Whitney U Test, Fisher Exact Test and Chi Square Test. The validity of the tests was estimated using the area under the ROC curve (AUROC) with a confidence interval of $95 \%(95 \% \mathrm{CI})$. In addition, the data was analyzed by logistic regression models using the "Enter" method to estimate additional risk predicted by each individual variable. 


\section{RESULTS}

According to the bleeding risk, the study lot (130 patients) was divided into: Group I (low bleeding risk), which included 102 patients, and Group II (high bleeding risk), which included 28 patients.

Parameters found to have statistically significant differences between the two groups were transaminases, platelet count, spleen size, INR, portal vein diameter and both liver and spleen elastography. Age, gender, hemoglobin, and body mass index parameters did not have a significant statistical difference between the two groups in the initial univariate analysis.

Table 1 presents AUROC for each parameter found relevant in the initial univariate analysis and identifies spleen elastography as having the best result (Figure 1), followed by INR, AST and platelet count. Liver elastography had the worst performance out of all parameters analyzed.

Logistic regression was performed for all parameters and the following parameters were determined to be part of the model as independent variables: spleen elastography, INR, platelet count, spleen diameter, ALT, age, and gender (Table 2).

Table 1

Parameter accuracy

\begin{tabular}{|c|c|c|}
\hline Parameter & $\operatorname{AUROC}^{4}\left(95 \% \mathrm{CI}^{5}\right)$ & P-value (statistic test) \\
\hline $\mathrm{AST}^{1}$ & $0.769(0.687-0.839)$ & 0.005 (Independent Samples T-test) \\
\hline $\mathrm{ALT}^{2}$ & $0.657(0.569-0.738)$ & 0.01 (Mann-Whitney) \\
\hline Platelet Count & $0.740(0.751-0.829)$ & $<0.001$ (Mann-Whitney) \\
\hline Spleen size & $0.723(0.638-0.798)$ & $<0.001$ (Independent Samples T-test) \\
\hline $\mathrm{INR}^{3}$ & $0.776(0.695-0.845)$ & $<0.001$ (Mann-Whitney) \\
\hline Portal vein diameter & $0.695(0.608-0.774)$ & 0.002 (Independent Samples T-test) \\
\hline Liver elastography & $0.627(0.538-0.710)$ & 0.021 (Independent Samples T-test) \\
\hline Spleen elastography & $0.863(0.791-0.917)$ & $<0.001$ (Independent Samples T-test) \\
\hline
\end{tabular}

${ }^{1}$ aspartate aminotransferase, ${ }^{2}$ alanine aminotransferase, ${ }^{3}$ International Normalized Ratio, ${ }^{4}$ area under receiver operating characteristic, ${ }^{5} 95 \%$ confidence interval.

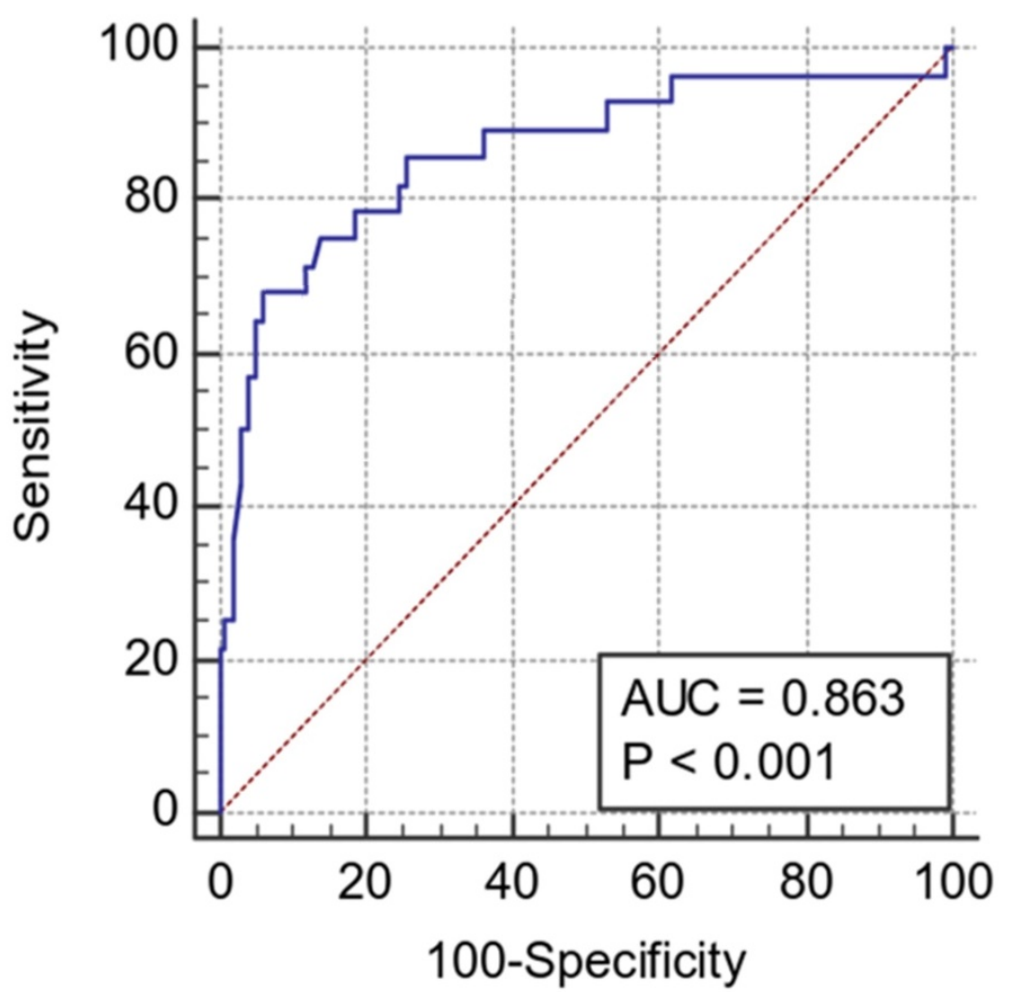

Figure 1. AUROC for spleen elastography. 
Table 2

Logistic regression

\begin{tabular}{|l|c|c|c|}
\hline Parameter & Odds ratio & $\mathbf{9 5 \%}$ Confidence Interval & p-value \\
\hline Age & 0.8465 & $0.7169-0.9995$ & 0.0493 \\
\hline Gender = M & 0.0121 & $0.0006-0.2377$ & 0.0037 \\
\hline ALT $^{1}$ & 1.0453 & $1.0071-1.0849$ & 0.0198 \\
\hline Platelet Count $_{\text {INR }^{2}}$ & 1.0000 & $0.9999-1.0000$ & 0.0070 \\
\hline Spleen elastography & 320000 & $96.7650-10600000000$ & 0.0022 \\
\hline
\end{tabular}

aspartate aminotransferase, ${ }^{2}$ International Normalized Ratio.

\section{DISCUSSION}

Our study showed that spleen stiffness was the best noninvasive method of identifying patients with high-risk varices. Logistic regression also shows significant accuracy for spleen stiffness. Other parameters like AST, ALT, platelet count, spleen size, INR, portal vein diameter, liver elastography were much weaker in diagnosing the presence of varices with a high risk of bleeding.

Variceal bleeding is one of the most important complications of portal hypertension. Thus, the need to identify patients with high-risk varices is crucial. The current gold standard methods of identifying these patients are hepatic venous pressure gradient (HVPG) and upper digestive endoscopy. Unfortunately, both methods are invasive, have a high cost and require specialized personal. Consequently, various non-invasive methods have been proposed to circumvent the need for upper digestive endoscopy or HVPG.

Current guidelines recommend usage of the Baveno VI criteria (liver stiffness measured by transient elastography with values under $20 \mathrm{kPa}$ plus a platelet count of over 150,000) to identify patients with a low risk of having varices which require treatment [5]. With the Baveno VI criteria approximately $26 \%$ of endoscopies can be avoided in patients with high-risk varices [6]. Because the number of unnecessary endoscopies still being performed is high, the Expanded Baveno VI criteria were established (liver stiffness measured by transient elastography with values under $25 \mathrm{kPa}$ plus a platelet count of over 110,000) [10]. With the Expanded Baveno VI criteria more endoscopies can be avoided in patients with high-risk varices (approximately $31 \%$ ), but with a higher error rate compared to the classic Baveno VI criteria [6]. Hepatic elastography used as a single parameter showed poor results in predicting high risk varices [11-13]. Combining hepatic elastography with platelet count significantly increases diagnostic performance.
Spleen stiffness is a novel parameter that has shown promise in diagnosing both clinically significant portal hypertension (HVPG $\geq 10 \mathrm{mmHg}$ ) and severe portal hypertension (HVPG $>12 \mathrm{mmHg}$ ) in multiple studies [14-18]. Portal hypertension leads to activation of the mTOR (mammalian target of rapamycin) pathway which in turn activates fibrogenesis, angiogenesis, expansion of lymphatic compartment in the spleen $[19,20]$. Thus, portal hypertension induces spleen fibrogenesis, and as a result portal hypertension correlates with spleen stiffness.

In a recent meta-analysis which evaluated 7 studies, spleen stiffness showed excellent performance in identifying clinical significant portal hypertension (AUROC 0.92) and severe portal hypertension (AUROC 0.91) [21]. The same meta-analysis showed that spleen stiffness (17 studies) was a good method of diagnosing patients with high-risk varices (AUROC 0.83 ) with a pooled sensitivity of $87 \%$ and a pooled specificity of $66 \%$ [21]. It is important to point out that this meta-analysis included multiple elastography techniques (transient elastography, point shear-wave elastography, two-dimensional shear wave elastography, magnetic resonance elastography), each with its advantages and disadvantages [21]. Another meta-analysis which included 7 studies also showed that spleen stiffness was a good predictor of high risk esophageal varices (AUROC 0.807) [22]. Studies which used point shear-wave elastography like in our study, showed that spleen stiffness was a good method of predicting high risk varices [13, 23-25]. The cut-off values and performance of spleen stiffness varied in studies because most studies included multiple etiologies, different measuring techniques and different protocols.

Other parameters like laboratory data, or scores that use laboratory values like aspartate aminotransferase-to-platelet ratio (APRI), aspartate aminotransferase-to-alanine aminotransferase ratio (AAR), FIB-4, Lok have showed low to moderate diagnostic accuracy in predicting the presence of high-risk esophageal varices [26, 27]. 
In regard to platelet count, one large study shows that, as a standalone factor, it is not a significant predictor of unprovoked variceal bleeding [28]. However, both INR and platelet count should be treated in patients where high-risk procedures need to be performed as well as in patients with active bleeding [29].

Models that include age, platelet count (Fib-4 score) were found to be useful but not accurate in predicting variceal bleeding. Other models including the aspartate aminotransferase (AST) to alanine aminotransferase (ALT) ratio (AST/ALT), AST to platelet ratio index (APRI), platelet count to spleen diameter (PC/SD), fibrosis index (FI) and King's Score, were found to not be useful [30].
Some of the limitations of our study are the fact that we did not perform HVPG to properly assess portal hypertension and instead used upper digestive endoscopy which is a subjective technique. The number of patients included was small which led to wide confidence intervals. We also did not compare our results to other elastography techniques such as transient elastography.

\section{CONCLUSIONS}

Spleen stiffness is the best noninvasive method of predicting the presence of high-risk esophageal varices. Future studies need to be elaborated to assess the diagnostic performance of spleen stiffness.

Introducere. Endoscopia digestivă superioară rămâne standardul de aur pentru diagnosticarea varicelor esofagiene sau gastrice, dar procedura este invazivă şi des însoţită de complianţă scăzută din partea pacienţilor. Scopul studiului a fost identificarea parametrilor non-invazivi care pot fi încorporaţi intr-un algoritm pentru estimarea riscului de hemoragie variceală.

Material şi metode. S-a realizat un studiu prospectiv pe 130 pacienţi cirotici. Pacienţii au efectuat teste ce au inclus enzime hepatice, hemogramă completă, parametrii de coagulare, ecografie abdominală şi elastografie a ficatului şi splinei. Endoscopia digestivă superioară s-a realizat pentru toţi pacienţii incluşi în studiu, rezultatele impărţind pacienţii în două categorii, în concordanţă cu clasificarea Baveno: Grupul 1 - pacienţi cu risc de sângerare scăzut şi Grupul 2 - pacienţi care necesită tratament profilactic.

Rezultate. Lotul de studiu (130 pacienţi) a fost împărţit în: Grupul 1 (risc scăzut de sângerare - 102 pacienţi) şi Grupul 2 (risc crescut de sângerare - 28 pacienţi). Parametrii descoperiţi cu diferenţe semnificative în analiza univariată au fost transaminazele, trombocitele, axul lung al splinei, INR, diametrul venei porte şi elastografia ficatului şi splinei. Calculând AUROC pentru fiecare parametru, identificăm elastografia splenică ca având cel mai bun rezultat, urmat de INR, AST şi trombocite. Elastografia hepatică a avut cel mai slab AUROC. Variabilele independente identificate prin regresia logistică au inclus elastografia splenică, INR, trombocitele, diametrul splinei, ALT, vârsta şi sexul.

Concluzii: Elastografia splenică este cea mai bună metodă de a prezice varicele esofagiene cu risc înalt de sângerare.

Correspondence to: Alexandru Constantin Moldoveanu, MD, Ph.D, University Emergency Hospital Bucharest - Splaiul Independentei nr. 169, Sector 5, Bucharest, Romania

Mobile: +40742224204

E-mail: alexandru@moldoveanu.tel

Conflict of interest disclosure: The authors declare that there are no conflicts of interest.

\section{REFERENCES}

1. GARCIA-TSAO G, SANYAL A, GRACE N, CAREY W. Practice Guidelines Committee of American Association for Study of Liver Diseases. Practice Parameters Committee of American College of Gastroenterology. Am J Gastroenetrol. 2007; 102(9): 2086-102. doi: 10.1002/hep.28906. 
2. NASHAAT EH, ABD-ELAZIZ H, SABRY M, IBRAHIM AA. Non-Endoscopic Predictors of Esophageal Varices and Portal Hypertensive Gastropathy. Nature and Science. 2010; 8(6):43-50.

3. UMAR A, QAZI ARISAR FA, SATTAR R, AHSAN B. Non-invasive parameters for the detection of variceal bleed in patients of liver cirrhosis, an experience of a tertiary care hospital in Pakistan. Asian Journal of Medical Sciences. 2014 08/15; 6(1):61-6. doi: 10.3126/ajms.v6i1.9624.

4. VILLANUEVA C, ARACIL C, COLOMO A, HERNÁNDEZ-GEA V, LÓPEZ-BALAGUER JM, ALVAREZ-URTURI C, TORRAS X, BALANZÓ J, GUARNER C. Acute hemodynamic response to beta-blockers and prediction of long-term outcome in primary prophylaxis of variceal bleeding. Gastroenterology. $2009 \mathrm{Jul}$; 137(1):119-28. doi: 10.1053/j.gastro.2009.03.048.

5. DE FRANCHIS R. Expanding consensus in portal hypertension: Report of the Baveno VI Consensus Workshop: Stratifying risk and individualizing care for portal hypertension. J Hepatol. 2015 Sep; 63(3):743-52. doi: 10.1016/j.jhep.2015.05.022.

6. STAFYLIDOU M, PASCHOS P, KATSOULA A, MALANDRIS K, IOAKIM K, BEKIARI E, HAIDICH AB, AKRIVIADIS E, TSAPAS A. Performance of Baveno VI and Expanded Baveno VI Criteria for Excluding High-Risk Varices in Patients With Chronic Liver Diseases: A Systematic Review and Meta-analysis. Clin Gastroenterol Hepatol. 2019 Aug; 17(9):1744-55.e11. doi: 10.1016/j.cgh.2019.04.062.

7. AUGUSTIN S, PONS M, MAURICE JB, BUREAU C, STEFANESCU H, NEY M, BLASCO H, PROCOPET B, TSOCHATZIS E, WESTBROOK RH, BOSCH J, BERZIGOTTI A, ABRALDES JG, GENESCÀ J. Expanding the Baveno VI criteria for the screening of varices in patients with compensated advanced chronic liver disease. Hepatology. 2017; 66(6): 1980-8. doi: 10.1002/hep.29363.

8. DAGRADI AE. The natural history of esophageal varices in patients with alcoholic liver cirrhosis. An endoscopic and clinical study. Am J Gastroenterol. 1972 Jun; 57(6):520-40.

9. PALMER ED, BRICK IB. Correlation between the severity of esophageal varices in portal cirrhosis and their propensity toward hemorrhage. Gastroenterology. 1956 Jan; 30(1):85-90.

10. AUGUSTIN S, PONS M, MAURICE JB, BUREAU C, STEFANESCU H, NEY M, BLASCO H, PROCOPET B, TSOCHATZIS E, WESTBROOK RH, BOSCH J, BERZIGOTTI A, ABRALDES JG, GENESCA J. Expanding the Baveno VI criteria for the screening of varices in patients with compensated advanced chronic liver disease. Hepatology (Baltimore, Md). 2017 Dec; 66(6):1980-8. doi: 10.1002/hep.29363.

11. KIM TY, JEONG WK, SOHN JH, KIM J, KIM MY, KIM Y. Evaluation of portal hypertension by real-time shear wave elastography in cirrhotic patients. Liver Int. 2015 Nov; 35(11):2416-24. doi: 10.1111/liv.12846.

12. VERMEHREN J, POLTA A, ZIMMERMANN O, HERRMANN E, POYNARD T, HOFMANN WP, BOJUNGA J, SARRAZIN C, ZEUZEM S, FRIEDRICH-RUST M. Comparison of acoustic radiation force impulse imaging with transient elastography for the detection of complications in patients with cirrhosis. Liver Int. 2012 May; 32(5):852-8. doi: 10.1111/j.1478-3231.2011. 02736.x.

13. FIERBINTEANU-BRATICEVICI C, TRIBUS L, PEAGU R, PETRISOR A, BAICUS C, CRETOIU D, PASTERNAK A, OPREA G, PURCAREANU A, MOLDOVEANU AC. Spleen Stiffness as Predictor of Esophageal Varices in Cirrhosis of Different Etiologies. Scientific Reports. 2019 2019/11/07; 9(1):16190. doi: 10.1038/s41598-019-52407-y.

14. COLECCHIA A, MONTRONE L, SCAIOLI E, BACCHI-REGGIANI ML, COLLI A, CASAZZA G, SCHIUMERINI R, TURCO L, DI BIASE AR, MAZZELLA G, MARZI L, ARENA U, PINZANI M, FESTI D. Measurement of spleen stiffness to evaluate portal hypertension and the presence of esophageal varices in patients with HCV-related cirrhosis. Gastroenterology. 2012 Sep; 143(3):646-54. doi: 10.1053/j.gastro.2012.05.035.

15. TAKUMA Y, NOUSO K, MORIMOTO Y, TOMOKUNI J, SAHARA A, TAKABATAKE H, MATSUEDA K, YAMAMOTO H. Portal Hypertension in Patients with Liver Cirrhosis: Diagnostic Accuracy of Spleen Stiffness. Radiology. 2016 May; 279(2): 609-19. doi: 10.1148/radiol.2015150690.

16. ATTIA D, SCHOENEMEIER B, RODT T, NEGM AA, LENZEN H, LANKISCH TO, MANNS M, GEBEL M, POTTHOFF A. Evaluation of Liver and Spleen Stiffness with Acoustic Radiation Force Impulse Quantification Elastography for Diagnosing Clinically Significant Portal Hypertension. Ultraschall in der Medizin (Stuttgart, Germany : 1980). 2015 Dec; 36(6):603-10. doi: $10.1055 / \mathrm{s}-0041-107971$.

17. ELKRIEF L, RAUTOU PE, RONOT M, LAMBERT S, DIOGUARDI BURGIO M, FRANCOZ C, PLESSIER A, DURAND F, VALLA D, LEBREC D, VILGRAIN V, CASTERA L. Prospective comparison of spleen and liver stiffness by using shear-wave and transient elastography for detection of portal hypertension in cirrhosis. Radiology. 2015 May; 275(2):589-98. doi: 10.1148/radiol.14141210.

18. JANSEN C, BOGS C, VERLINDEN W, THIELE M, MÖLLER P, GÖRTZEN J, LEHMANN J, VANWOLLEGHEM T, VONGHIA L, PRAKTIKNJO M, CHANG J, KRAG A, STRASSBURG CP, FRANCQUE S, TREBICKA J. Shear-wave elastography of the liver and spleen identifies clinically significant portal hypertension: A prospective multicentre study. Liver International. 2017; 37(3):396-405. doi: 10.1111/liv.13243.

19. CHEN Y, WANG W, WANG H, LI Y, SHI M, LI H, YAN J. Rapamycin Attenuates Splenomegaly in both Intrahepatic and Prehepatic Portal Hypertensive Rats by Blocking mTOR Signaling Pathway. PLoS One. 2016; 11(1):e141159. doi: 10.1371/ journal.pone.0141159.

20. MEJIAS M, GARCIA-PRAS E, GALLEGO J, MENDEZ R, BOSCH J, FERNANDEZ M. Relevance of the mTOR signaling pathway in the pathophysiology of splenomegaly in rats with chronic portal hypertension. J Hepatol. 2010 Apr; 52(4):529-39. doi: 10.1016/j.jhep.2010.01.004.

21. HU X, HUANG X, HOU J, DING L, SU C, MENG F. Diagnostic accuracy of spleen stiffness to evaluate portal hypertension and esophageal varices in chronic liver disease: a systematic review and meta-analysis. European Radiology. 2020 2020/09/24. doi: 10.1007/s00330-020-07223-8.

22. MANATSATHIT W, SAMANT H, KAPUR S, INGVIYA T, ESMADI M, WIJARNPREECHA K, MCCASHLAND T. Accuracy of liver stiffness, spleen stiffness, and LS-spleen diameter to platelet ratio score in detection of esophageal varices: Systemic review and meta-analysis. Journal of gastroenterology and hepatology. 2018; 33(10):1696-706. doi: 10.1111/jgh.14271. 
23. PEAGU R, SARARU R, NECULA A, MOLDOVEANU A, PETRISOR A, FIERBINTEANU-BRATICEVICI C. The role of spleen stiffness using ARFI in predicting esophageal varices in patients with Hepatitis $B$ and $C$ virus-related cirrhosis. Rom $\mathrm{J}$ Intern Med. 2019 Jul 12; 57:334-40. doi: 10.2478/rjim-2019-0017.

24. TAKUMA Y, NOUSO K, MORIMOTO Y, TOMOKUNI J, SAHARA A, TOSHIKUNI N, TAKABATAKE H, SHIMOMURA H, DOI A, SAKAKIBARA I, MATSUEDA K, YAMAMOTO H. Measurement of spleen stiffness by acoustic radiation force impulse imaging identifies cirrhotic patients with esophageal varices. Gastroenterology. 2013 Jan; 144(1):92-101 e2. doi: 10.1053/ j.gastro.2012.09.049.

25. KIM TY, KIM TY, KIM Y, LIM S, JEONG WK, SOHN JH. Diagnostic Performance of Shear Wave Elastography for Predicting Esophageal Varices in Patients With Compensated Liver Cirrhosis. J Ultrasound Med. 2016 Jul; 35(7):1373-81. doi: 10.7863/ ultra.15.07024.

26. DENG H, QI X, GUO X. Diagnostic Accuracy of APRI, AAR, FIB-4, FI, King, Lok, Forns, and FibroIndex Scores in Predicting the Presence of Esophageal Varices in Liver Cirrhosis: A Systematic Review and Meta-Analysis. Medicine. 2015; 94(42):e1795-e. doi: 10.1097/MD.0000000000001795.

27. ZHANG F, LIU T, GAO P, FEI S. Predictive Value of a Noninvasive Serological Hepatic Fibrosis Scoring System in Cirrhosis Combined with Oesophageal Varices. Canadian journal of gastroenterology \& hepatology. 2018; 2018:7671508. doi: 10.1155/ 2018/7671508.

28. BASILI S, RAPARELLI V, NAPOLEONE L, TALERICO G, CORAZZA GR, PERTICONE F, SACERDOTI D, ANDRIULLI A, LICATA A, PIETRANGElO A, PICARDi A, RAIMONDO G, VIOLI F. Platelet Count Does Not Predict Bleeding in Cirrhotic Patients: Results from the PRO-LIVER Study. Am J Gastroenterol. 2018 Mar; 113(3):368-75. doi: 10.1038/ajg. 2017.457.

29. O'LEARY JG, GREENBERG CS, PATTON HM, CALDWELl SH. AGA Clinical Practice Update: Coagulation in Cirrhosis. Gastroenterology. 2019 Jul; 157(1):34-43.e1. doi: 10.1053/j.gastro.2019.03.070.

30. KRAJA B, MONE I, AKSHIJA I, KOÇOLLARI A, PRIFTI S, BURAZERI G. Predictors of esophageal varices and first variceal bleeding in liver cirrhosis patients. World J Gastroenterol. 2017 Jul 14; 23(26):4806-14. doi: 10.3748/wjg.v23.i26.4806.

Received $29^{\text {th }}$ December 2020 